\title{
Identification of main contamination points by hygiene indicator microorganisms in beef processing plants
}

\author{
Identificação dos principais pontos de contaminação por microrganismos \\ indicadores de higiene em plantas de processamento de carnes
}

Márcia de Aguiar Ferreira BARROS ${ }^{1,2 *}$, Luís Augusto $\mathrm{NERO}^{2,3}$, Alexandre Amorim MONTEIRO ${ }^{2}$, Vanerli BELOTI ${ }^{2}$

\begin{abstract}
The microbiological quality of beef and meat products is strongly influenced by the conditions of hygiene prevailing during their production and handling. Without proper hygienic control, the environment in slaughterhouses and butcher shops can act as an important source of microbiological contamination. To identify the main points of microbiological contamination in the beef processing chain, 443 samples of equipment, installations and products were collected from 11 establishments ( 1 slaughterhouse and 10 butcher shops) located in the state of Paraná, Brazil. The microbiological quality of all the samples was evaluated using Petri dishes to obtain counts of mesophilic aerobes (AC), total coliforms, Escherichia coli (EC), yeasts and molds (YM). The main contamination points identified in butcher shops, in decreasing order, were stainless steel boxes, beef tenderizers, grinders, knives, mixers, sausage stuffers, plastic boxes, floors and drains. In the slaughterhouse, these points were sausage stuffers, platforms, floors and drains. The most severely contaminated products were fresh sausages and ground beef. This information about the main points of microbiological contamination in the beef processing chain is expected to aid professionals responsible for hygiene in similar establishments to set up proper hygienic procedures to prevent or reduce microbiological contamination of beef and meat products.
\end{abstract}

Keywords: beef; contamination; indicator microorganisms; meat processing; Escherichia coli.

\section{Resumo}

A qualidade microbiológica de carne e derivados é altamente influenciada pelas condições higiênicas durante sua produção e manipulação. Sem um controle higiênico adequado, o ambiente de abatedouros e açougues pode representar um importante ponto de contaminação. Com o objetivo de identificar os principais pontos de contaminação microbiológica na linha de processamento de carne, 443 amostras de equipamentos, instalações e produtos foram coletados em 11 estabelecimentos ( 1 abatedouro e 10 açougues) localizados no Estado do Paraná, Brasil. A qualidade microbiológica das amostras foi determinada utilizando-se placas Petrifilm ${ }^{\mathrm{TM}}$ para contagem de aeróbios mesófilos (AC), coliformes totais e Escherichia coli (EC) e bolores e leveduras (YM). Nos açougues os principais pontos de contaminação identificados, em ordem decrescente, foram caixas de aço inoxidável, amaciadores de carnes, moedores, facas, misturadores, embutideiras, caixas plásticas, pisos e ralos. No abatedouro, os principais pontos foram embutideiras, superfícies da plataforma de abate, pisos e ralos. Os produtos cárneos que apresentaram maiores níveis de contaminação foram lingüiças frescas e carne moída. Esse trabalho identificou os principais pontos de contaminação microbiológica na linha de processamento de carne, podendo direcionar profissionais responsáveis pelas condições higiênicas na obtenção desses produtos na determinação de procedimentos higiênicos adequados, para evitar ou reduzir a contaminação microbiológica em carne e seus derivados.

Palavras-chave: carne bovina; contaminação; microrganismos indicadores; processamento; Escherichia coli.

\section{Introduction}

Meat is considered an important source of proteins, essential amino acids, B complex vitamins and minerals. Due to this rich composition, it offers a highly favorable environment for the growth of pathogenic bacteria. The microbiological contamination of carcasses occurs mainly during processing and manipulation, such as skinning, evisceration, processing, storage and distribution at slaughterhouses and retail establishments ${ }^{9}$. Fecal matter is a major source of contamination and can reach carcasses through direct deposition, as well as by indirect contact through contaminated and clean carcasses, equipment, workers, installations and $\mathrm{air}^{2}$.

Contamination levels up to $10^{5}$ CFU.cm ${ }^{-2}$ indicate good hygienic conditions during slaughtering while higher levels

Recebido para publicação em 26/12/2006

Aceito para publicação em 23/7/2007 (002175)

' Faculdade de Agronomia e Medicina Veterinária, Universidade de Brasília - UnB,

Campus Darcy Ribeiro, CP 4508, CEP 70910-970, Brasília - DF, Brasil

E-mail:mafer@unb.br

Departamento de Medicina Veterinária Preventiva,

Universidade Estadual de Londrina - UEL, Londrinha - PR, Brasil

Departamento de Veterinária, Universidade Federal de Viçosa - UFV

* A quem a correspondencia deve ser enviada indicate unsatisfactory conditions. Meat contamination of $10^{6}$ CFU. $\mathrm{cm}^{-2}$ indicates a deterioration process with off odors and reduction of shelf life and, when the contamination reaches $10^{7} \mathrm{CFU}_{\mathrm{cm}}{ }^{2}$, slime formation is already evident ${ }^{9}$. The most efficient way of reducing contamination and microbial growth in meat is to establish quality control programs such as Good Manufacturing Practices (GMP) and Hazard Analysis of Critical Control Points (HACCP), which can be conducted by seeking indicator microorganisms that predict the presence of pathogens and bacteria causing spoilage ${ }^{14}$.

With regard to raw meat products, their safety and quality can be estimated based on indicator microorganism counts, including mesophilic aerobes (MA), total coliforms (TC) and Escherichia coli (EC). MA counts provide an estimation of the total microbial population, and high levels of MA are usually correlated to low quality and reduced shelf life ${ }^{8,14}$. TC and EC counts allow one to verify hygiene-related problems and contamination of fecal origin. High TC and EC counts are usually associated with significant levels of enteric pathogens ${ }^{5,6,14}$. According to the USDA Pathogen Reduction Act ${ }^{17}$ policy, the regulation of meat and poultry inspection has made the examination of $E$. coli in carcasses compulsory. 
Mold counts have served as indicators of sanitary quality in food processing plants, since molds can grow rapidly on rests of food adhering to surfaces, thus representing a possible source of contamination. Several molds can pose risks to human and animal health because of their production of toxic metabolites known as mycotoxins ${ }^{4}$.

This work involved an evaluation of the microbiological quality of raw meat and the hygienic-sanitary conditions of processing plants, based on the presence of indicator microorganisms in meat, equipment and processing facilities. Another goal was to identify the main points of contamination and incorporation of these microorganisms in meat, with a view to the adoption of Good Manufacturing Practices in meat processing establishments by the professionals responsible for hygienic production conditions, thereby improving the microbiological quality of the product.

\section{Materials and methods}

\subsection{Samples and dilution}

Eleven meat processing establishments (10 meat retail establishments and 1 slaughterhouse) in Brazil were selected randomly and samples were collected from different points of the processing plants, as indicated in Table 1. The samples were collected during a single visit to the slaughterhouse, and during at least two visits to each retail establishment. Samples were collected from surfaces by swabbing a delimited area ${ }^{1}$ with sterile swabs (Quick Swab, 3M Microbiology, St. Paul, MN, USA) and templates. $200 \mathrm{~g}$ of ground beef and fresh and cooked sausage samples were collected and $5 \mathrm{~g}$ of each sample were analyzed microbiologically. All the samples were diluted in $45 \mathrm{~mL}$ of buffered peptone water 0.1\% (Oxoid, Basingstoke, U.K.) and serial decimal dilutions were prepared in $\mathrm{NaCl} 0.85 \%$.

\subsection{Microbiological analysis}

The diluted samples were used for the enumeration of indicator microorganism counts using Petrifilm ${ }^{\mathrm{TM}}$ plates $(3 \mathrm{M}$ Microbiology, St. Paul, MN, USA). Petrifilm ${ }^{\mathrm{TM}}$ AC was used for mesophilic aerobes, Petrifilm ${ }^{\mathrm{TM}}$ EC for total coliforms and E. coli, and Petrifilm ${ }^{\mathrm{TM}} \mathrm{YM}$ for yeasts and molds, according to the manufacturer's instructions $(1 \mathrm{~mL}$ of selected dilution for each plate, no duplicates, and 24-48 hours at $35^{\circ} \mathrm{C}$ for AC and EC plates, and $3-5 \mathrm{~d}$ at $25^{\circ} \mathrm{C}$ for YM plates). After incubation, all the colonies formed on plates were counted and the results were converted to CFU. $\mathrm{cm}^{-2}$ or CFU.g ${ }^{-2}$, considering the sample, dilution and sampled area.

\subsection{Statistical analysis}

The results of indicator microorganism counts were converted into $\log _{10}$ and several statistical parameters (mean,

Table 1. Sampling points, sample size and surface sampling area in beef processing plants and retail establishments in Brazil.

\begin{tabular}{|c|c|c|c|c|}
\hline \multirow[t]{2}{*}{ Sample origin } & Meat retail establishments & Slaughterhouse & Total & Area/sample quantity \\
\hline & $\mathrm{n}$ & $\mathrm{n}$ & $\mathrm{n}$ & $\mathrm{cm}^{2} \cdot \mathrm{g}^{-1}$ \\
\hline Beef tenderizer & 8 & - & 8 & $30 \mathrm{~cm}^{2}$ \\
\hline Plastic boxes & 26 & 2 & 28 & $30 \mathrm{~cm}^{2}$ \\
\hline Stainless steel boxes & 10 & - & 10 & $30 \mathrm{~cm}^{2}$ \\
\hline Sausage stuffers & 2 & 1 & 3 & $30 \mathrm{~cm}^{2}$ \\
\hline Knives & 15 & 6 & 21 & $30 \mathrm{~cm}^{2}$ \\
\hline Hooks & 7 & 3 & 10 & Surface area \\
\hline Tables & 20 & 1 & 21 & $60 \mathrm{~cm}^{2}$ \\
\hline Mixers & 3 & 1 & 4 & $30 \mathrm{~cm}^{2}$ \\
\hline Grinders & 9 & 1 & 10 & $30 \mathrm{~cm}^{2}$ \\
\hline Meat saw & 10 & - & 10 & $30 \mathrm{~cm}^{2}$ \\
\hline Floors & 9 & 1 & 10 & $60 \mathrm{~cm}^{2}$ \\
\hline Platforms & - & 5 & 5 & $60 \mathrm{~cm}^{2}$ \\
\hline Drains & 18 & 7 & 25 & Surface area \\
\hline Refrigeration systems & 4 & - & 4 & $60 \mathrm{~cm}^{2}$ \\
\hline \multicolumn{5}{|l|}{ Products } \\
\hline Bovine carcasses & 142 & 9 & 151 & $50 \mathrm{~cm}^{2}$ \\
\hline Swine carcasses & - & 3 & 3 & $50 \mathrm{~cm}^{2}$ \\
\hline Ground beef & 12 & - & 12 & $5 \mathrm{~g}$ \\
\hline Comercial cuts & 51 & 1 & 52 & $50 \mathrm{~cm}^{2}$ \\
\hline Cooked sausages & - & 2 & 2 & $5 \mathrm{~g}$ \\
\hline Fresh sausages & 10 & - & 10 & $5 \mathrm{~g}$ \\
\hline
\end{tabular}


standard deviation, variance, standard error, minimum and maximum) were calculated considering the type of sample and origin, using Statistica 6.0 software (StatSoft, Inc., Tulsa, Oklahoma, USA).

\section{Results and discussion}

The average contamination level by MA in samples from meat retail establishments and slaughterhouse equipment was $4.68 \log$ CFU.cm-2 (Table 2). The average contamination level of TC was $2.55 \log$ CFU.cm ${ }^{-2}$ (Table 3) and that of EC was $1.80 \log$ CFU.cm ${ }^{-2}$ (Table 4). The mean logarithmic counts of molds (3.20 log CFU.cm ${ }^{-2}$ ) and yeasts (3.21 log CFU.cm ${ }^{-2}$ ) are shown in Tables 5 and 6.

In the present study, with the exception of refrigeration systems, all the other types of equipment displayed average levels of MA contamination exceeding $10^{4}$ CFU. $\mathrm{cm}^{-2}$, which suffices to begin the formation of biofilm, according to HOOD and ZOTTOLA $^{11}$. This level of contamination was observed particularly in plastic boxes, beef tenderizers, sausage stuffers, mixers and grinders, which are difficult to clean and can accumulate large amounts of organic matter, favoring microbial growth and reducing the efficacy of sanitization procedures.

Despite their rectilinear shape, stainless steel boxes also showed high levels of contamination. Hence, basic failures occur in the sanitization procedures applied to these utensils, since some of the establishments were found not to apply the cleaning process on a daily basis. The knives used for filleting and cutting were not sanitized at any of the ten meat retail establishments visited. In the slaughterhouse, only some of the platforms (bleeding, evisceration and inspection line) adopted the practice of immersing knives in hot water.

As for the meat hooks for hanging carcasses, most of them were left on the floor in the establishments, and they were not cleaned prior to use. Although these hooks showed the highest average contamination levels, their contact with carcasses is restricted to the hind quarters, so they cannot be considered a usual contamination point, unlike other equipment. Most of the sampled pallets were made of wood, whose porous nature allows for water infiltration and the accumulation of organic matter. Their proximity to the floor also favors contamination.

Table 2. Statistical parameters of mesophilic aerobe counts (log CFU. $\mathrm{cm}^{-2}$ or g) in samples of equipment, installations, beef and beef products collected from 10 meat retail establishments and 1 slaughterhouse in Brazil.

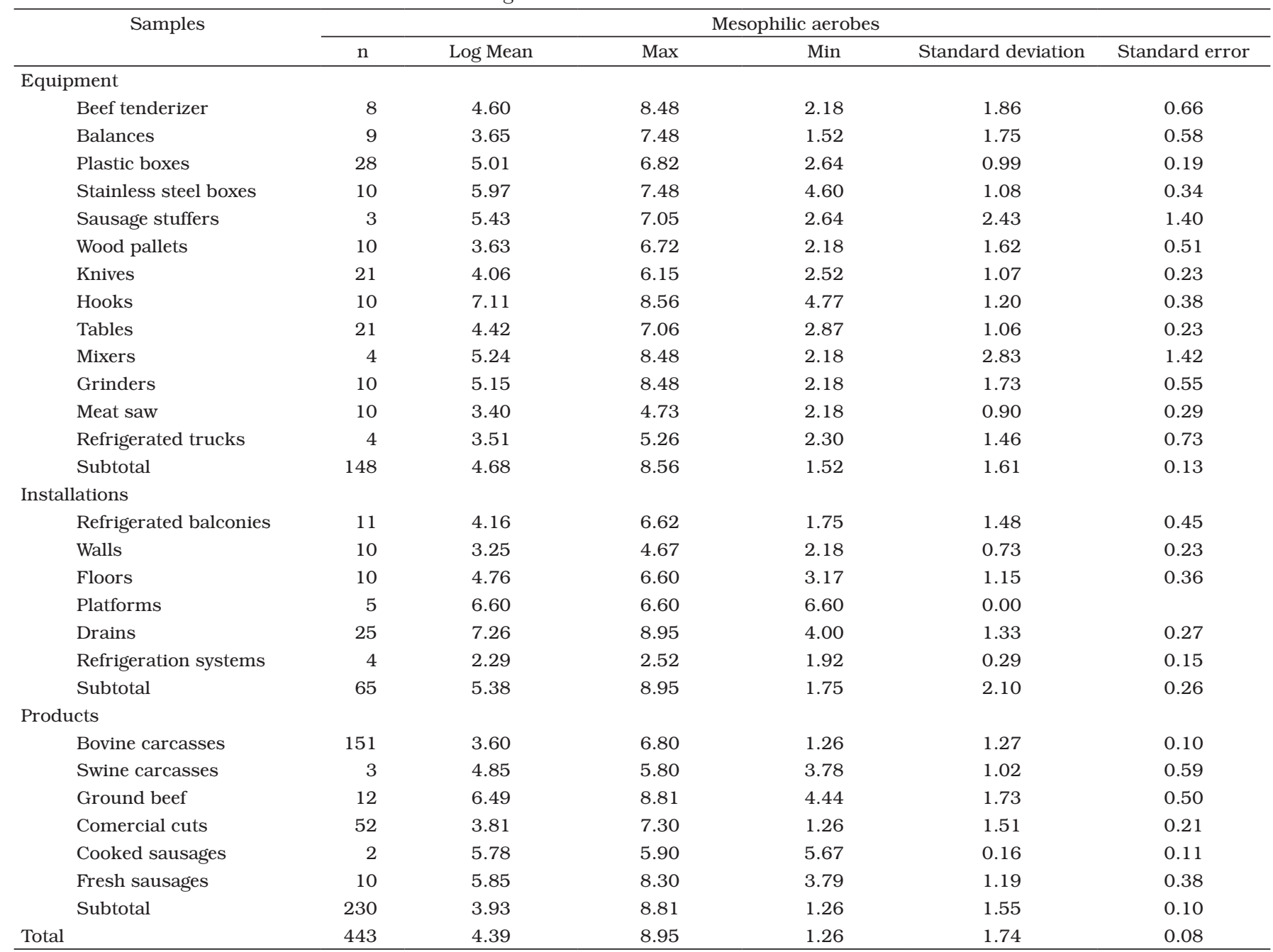


Table 3. Statistical parameters of total coliform counts (log CFU.cm-2 or g) in samples of equipment, installations, meat and meat products collected from 10 meat retail establishments and 1 slaughterhouse in Brazil

\begin{tabular}{|c|c|c|c|c|c|c|}
\hline \multirow[t]{2}{*}{ Samples } & \multicolumn{6}{|c|}{ Total Coliforms } \\
\hline & $\mathrm{n}$ & Log Mean & Max & Min & Standard deviation & Standard error \\
\hline \multicolumn{7}{|l|}{ Equipment } \\
\hline Beef tenderizer & 8 & 2.50 & 3.31 & 1.18 & 0.79 & 0.28 \\
\hline Balances & 9 & 1.49 & 3.08 & 0.52 & 0.93 & 0.31 \\
\hline Plastic boxes & 28 & 2.60 & 5.52 & 0.37 & 1.03 & 0.20 \\
\hline Stainless steel boxes & 10 & 3.34 & 4.92 & 1.78 & 0.92 & 0.29 \\
\hline Sausage stuffers & 3 & 3.04 & 5.30 & -0.18 & 2.86 & 1.65 \\
\hline Wood pallets & 10 & 1.52 & 2.52 & 0.52 & 0.64 & 0.20 \\
\hline Knives & 21 & 2.36 & 4.87 & -0.48 & 1.25 & 0.27 \\
\hline Hooks & 10 & 4.07 & 7.00 & 2.65 & 1.77 & 0.56 \\
\hline Tables & 21 & 2.50 & 3.48 & -0.48 & 0.90 & 0.20 \\
\hline Mixers & 4 & 3.03 & 4.89 & 1.18 & 1.77 & 0.88 \\
\hline Grinders & 10 & 3.11 & 5.30 & 1.18 & 1.29 & 0.41 \\
\hline Meat saw & 10 & 1.95 & 3.70 & 0.52 & 0.99 & 0.31 \\
\hline Refrigerated trucks & 4 & 1.89 & 3.95 & 1.00 & 1.38 & 0.69 \\
\hline Subtotal & 148 & 2.55 & 7.00 & -0.48 & 1.28 & 0.11 \\
\hline \multicolumn{7}{|l|}{ Installations } \\
\hline Refrigerated balconies & 11 & 1.96 & 3.81 & -0.48 & 1.39 & 0.42 \\
\hline Walls & 10 & 1.29 & 2.52 & 0.12 & 0.83 & 0.26 \\
\hline Floors & 10 & 2.26 & 5.30 & 0.90 & 1.23 & 0.39 \\
\hline Platforms & 5 & 5.30 & 5.30 & 5.30 & 0.00 & \\
\hline Drains & 25 & 4.90 & 7.00 & 3.00 & 1.33 & 0.27 \\
\hline Refrigeration systems & 4 & 1.75 & 2.52 & 1.18 & 0.57 & 0.29 \\
\hline Subtotal & 65 & 3.28 & 7.00 & -0.48 & 1.97 & 0.24 \\
\hline \multicolumn{7}{|l|}{ Products } \\
\hline Bovine carcasses & 143 & 1.49 & 4.95 & -0.05 & 1.15 & 0.10 \\
\hline Swine carcasses & 3 & 2.78 & 2.78 & 2.78 & 0.00 & \\
\hline Ground beef & 12 & 3.32 & 6.00 & 2.54 & 0.98 & 0.28 \\
\hline Comercial cuts & 50 & 1.68 & 5.58 & -0.05 & 1.28 & 0.18 \\
\hline Cooked sausages & 0 & - & - & - & - & - \\
\hline Fresh sausages & 10 & 3.27 & 4.88 & 1.00 & 1.13 & 0.36 \\
\hline Subtotal & 218 & 1.73 & 6.00 & -0.05 & 1.28 & 0.09 \\
\hline Total & 431 & 2.25 & 8.95 & -0.48 & 1.52 & 0.07 \\
\hline
\end{tabular}

The samples collected from facilities showed a logarithmic mean of $5.38 \mathrm{log}$ CFU.cm ${ }^{-2}$ of MA (Table 2); the average contamination level of TC was $3.28 \log$ CFU. $\mathrm{cm}^{-2}$ (Table 3); the logarithmic mean contamination of EC was $2.59 \log$ CFU.cm ${ }^{-2}$ (Table 4); and mold and yeast averages were $4.01 \mathrm{log}$ CFU.cm ${ }^{-2}$ and $4.10 \log$ CFU.cm ${ }^{-2}$, respectively (Tables 5 and 6).

EISEL et al. ${ }^{5}$ analyzed samples collected from equipment surfaces, floors and walls using the Petrifilm ${ }^{\mathrm{TM}}$ system for MA, TC and EC. Unlike our findings, however, their TC and EC counts were not significant, and the MA counts showed lower averages than those of our study. Floors are an important source of contamination, since they transfer contamination to workers' shoes. The workers, in turn, circulate inside the establishment, thereby disseminating the contamination. Even so, in several establishments, including the slaughterhouse, storage boxes containing retail cuts were found to be in direct contact with the floor in various locations (refrigerated rooms, filleting and retail cut rooms and sales department). The drains and floors can offer a favorable environment for microbial growth, and an important source of propagation and preservation of microorganisms, especially if cleaning is done with water under high pressure. This practice can spread contamination by suspending microorganisms in the air in droplets of water.

The analyzed products showed the following average counts: MA - $3.93 \log$ CFU.cm ${ }^{-2}$ or g (Table 2), TC - 1.73 log CFU.cm ${ }^{-2}$ or g (Table 3), EC - 1.13 log CFU.cm ${ }^{-2}$ or g (Table 4), mold $2.51 \log$ CFU.cm ${ }^{-2}$ or g, and yeast - $2.35 \log$ CFU.cm ${ }^{-2}$ or g (see Tables 5 and 6).

Microbiological counts higher than $10^{5}$ CFU.cm ${ }^{-2}$ in beef indicate deficient hygienic practices during processing, and this parameter is generally proposed by other countries ${ }^{9}$. Counts higher than $10^{6}$ CFU. $\mathrm{cm}^{-2}$ suffice to initiate the deterioration process $^{9,13}$. In a study of bovine carcasses at the end of processing in 10 establishments, GILL et al. ${ }^{8}$ estimated average MA counts of $3.30 \log$ CFU.cm ${ }^{-2}$; TC of $2 \log$ CFU. $100 \mathrm{~cm}^{-2}$ and EC of $1.18 \log$ CFU. $100 \mathrm{~cm}^{-2}$. GILL ${ }^{9}$ proposed counts below $1 \log$ CFU. $100 \mathrm{~cm}^{-2}$ as a criterion of acceptability, arguing that this level of EC can be achieved in bovine carcasses processed under hygienic conditions.

In an investigation involving 159 bovine carcasses of different sizes in Australian slaughterhouses, SUMNER et al. ${ }^{16}$ found 
Table 4. Statistical parameters of Escherichia coli counts (log CFU.cm ${ }^{-2}$ or g) in samples of equipment, installations, meat and meat products collected from 10 meat retail establishments and 1 slaughterhouse in Brazil

\begin{tabular}{|c|c|c|c|c|c|c|}
\hline \multirow[t]{2}{*}{ Samples } & \multicolumn{6}{|c|}{ Escherichia coli } \\
\hline & $\mathrm{n}$ & Log Mean & Max & Min & Standard deviation & Standard error \\
\hline Beef tenderizer & 8 & 1.57 & 2.52 & -0.48 & 0.99 & 0.35 \\
\hline Plastic boxes & 28 & 1.79 & 4.82 & -0.48 & 0.97 & 0.18 \\
\hline Stainless steel boxes & 10 & 1.92 & 4.18 & 1.18 & 0.92 & 0.29 \\
\hline Sausage stuffers & 3 & 1.60 & 4.11 & -0.48 & 2.33 & 1.34 \\
\hline Knives & 21 & 1.93 & 3.43 & -0.48 & 0.89 & 0.19 \\
\hline Hooks & 10 & 3.30 & 5.72 & 2.65 & 1.12 & 0.35 \\
\hline Tables & 21 & 1.73 & 3.00 & -0.48 & 0.98 & 0.21 \\
\hline Mixers & 4 & 2.31 & 3.96 & 1.18 & 1.18 & 0.59 \\
\hline Grinders & 10 & 1.94 & 4.60 & -0.48 & 1.32 & 0.42 \\
\hline Meat saw & 10 & 1.29 & 2.52 & -0.48 & 0.88 & 0.28 \\
\hline \multicolumn{7}{|l|}{ Installations } \\
\hline Walls & 10 & 1.23 & 2.52 & -0.48 & 0.94 & 0.30 \\
\hline Floors & 10 & 1.79 & 3.51 & -0.48 & 1.21 & 0.38 \\
\hline Platforms & 5 & 3.94 & 4.60 & 3.26 & 0.50 & 0.22 \\
\hline Drains & 25 & 3.88 & 6.30 & 1.00 & 1.23 & 0.25 \\
\hline Refrigeration systems & 4 & 1.54 & 2.52 & 0.92 & 0.70 & 0.35 \\
\hline Subtotal & 65 & 2.59 & 6.30 & -0.48 & 1.61 & 0.20 \\
\hline \multicolumn{7}{|l|}{ Products } \\
\hline Bovine carcasses & 143 & 1.01 & 3.48 & -0.05 & 0.86 & 0.07 \\
\hline Swine carcasses & 3 & 2.78 & 2.78 & 2.78 & 0.00 & - \\
\hline Ground beef & 12 & 2.13 & 4.85 & 1.00 & 0.94 & 0.27 \\
\hline Comercial cuts & 50 & 1.01 & 4.76 & -0.05 & 0.94 & 0.13 \\
\hline
\end{tabular}

mean logarithmic contamination counts of $1.82 \log$ CFU.cm ${ }^{-2}$ for MA and $0.33 \log$ CFU.cm ${ }^{-2}$ for EC. These authors also employed the Petrifilm ${ }^{\mathrm{TM}}$ system for their microbiological analyses. PHILLIPS et al. ${ }^{15}$ also evaluated bovine carcasses $(\mathrm{n}=1268$ ) in Australian slaughterhouses and found mean logarithmic contamination counts of $2.42 \mathrm{log}$ CFU.cm ${ }^{-2}$ for MA and of $0.41 \log$ CFU.cm ${ }^{-2}$ for EC. One of the main sources of carcass contamination is the skin, which is usually associated with significant levels of contamination and a great variety of microorganisms ${ }^{12}$.

In an evaluation of the hygienic conditions of processed hamburger meat, GILL et al. ${ }^{7}$ reported that MA averages varied from 3.5 to $4.9 \log \mathrm{CFU} . \mathrm{g}^{-1}$, TC from 0.7 to $3.0 \log \mathrm{CFU} . \mathrm{g}^{-1}$, and EC from 0.2 to 2.6 log CFU.g ${ }^{-1}$. EISEL et al. ${ }^{5}$ reported average contamination in ground beef of $4.6 \mathrm{log} \mathrm{CFU} . \mathrm{g}^{-1}$ of MA, with TC counts varying from 1.4 to $3.2 \mathrm{log}$ CFU.g ${ }^{-1}$ and EC counts from 1 to $2 \log$ CFU.g ${ }^{-1}$. In an investigation of different readyto-eat meat products ( $\mathrm{n}=3494)$, GILLESPIE et al. ${ }^{10}$ found $8 \%$ of the samples had MA counts of $\geq 10^{7} \mathrm{CFU} . \mathrm{g}^{-1}$, while $3 \%$ of the samples had enteric bacteria counts of $\geq 10^{4} \mathrm{CFU} . \mathrm{g}^{-1}$, and EC counts of $\geq 10^{2}$ CFU.g $^{-1}$.
Brazilian legislation does not establish standards for contamination by MA, TC, EC or yeasts and molds in bovine carcasses and ground beef. The only parameter for raw refrigerated or frozen meat products (hamburgers, meatballs, kibbehkibbehkibbehs, etc.) and fresh sausages is thermotolerant coliforms $\left(5 \times 10^{2} \mathrm{CFU}_{\mathrm{g}} \mathrm{g}^{-1}\right)^{3}$. The findings of this study indicate higher levels of contamination by these microorganisms than those found in similar studies, especially in end products such as commercial cuts, ground beef and sausages. A careful analysis of the average microbiological counts in the products of our study suggests incremental contamination along the meat processing route, indicating that microorganisms are being incorporated throughout the process.

At the end of the study, the findings were reported to those in charge of hygiene at each establishment, and proper hygienic procedures were adopted for application in the most severely contaminated sites. In addition, several procedures were suggested to prevent or at least reduce microbiological contamination in beef processing. These procedures involve simple practices such as keeping plastic boxes off the floor, completely removing organic residues from machinery (grinders, mixers, 
Table 5. Statistical parameters of mold counts (log CFU.cm ${ }^{-2}$ or g) in samples of equipment, installations, meat and meat products collected from 10 meat retail establishments and 1 slaughterhouse in Brazil.

\begin{tabular}{|c|c|c|c|c|c|c|}
\hline \multirow[t]{2}{*}{ Samples } & \multicolumn{6}{|c|}{ Moulds } \\
\hline & $\mathrm{n}$ & Log Mean & Max & Min & Standard deviation & Standard error \\
\hline \multicolumn{7}{|l|}{ Equipment } \\
\hline Beef tenderizer & 7 & 2.86 & 4.08 & 2.18 & 0.69 & 0.26 \\
\hline Balances & 9 & 1.91 & 2.95 & 0.52 & 0.84 & 0.28 \\
\hline Plastic boxes & 25 & 3.64 & 6.30 & 1.67 & 1.26 & 0.25 \\
\hline Stainless steel boxes & 10 & 3.42 & 4.95 & 2.18 & 0.96 & 0.30 \\
\hline Sausage stuffers & 3 & 3.18 & 4.95 & 1.29 & 1.84 & 1.06 \\
\hline Wood pallets & 9 & 3.25 & 4.99 & 2.18 & 1.16 & 0.39 \\
\hline Knives & 19 & 2.78 & 3.52 & 2.00 & 0.56 & 0.13 \\
\hline Hooks & 10 & 5.21 & 7.78 & 3.65 & 1.25 & 0.39 \\
\hline Tables & 19 & 3.19 & 4.39 & 1.70 & 0.80 & 0.18 \\
\hline Mixers & 4 & 2.85 & 3.30 & 2.18 & 0.51 & 0.25 \\
\hline Grinders & 9 & 3.04 & 4.67 & 1.64 & 0.98 & 0.33 \\
\hline Meat saw & 9 & 2.30 & 3.44 & 0.52 & 0.85 & 0.28 \\
\hline Refrigerated trucks & 4 & 3.19 & 4.73 & 2.60 & 1.03 & 0.52 \\
\hline Subtotal & 137 & 3.20 & 7.78 & 0.52 & 1.20 & 0.10 \\
\hline \multicolumn{7}{|l|}{ Installations } \\
\hline Refrigerated balconies & 11 & 2.63 & 3.78 & 1.07 & 0.86 & 0.26 \\
\hline Walls & 9 & 2.71 & 5.30 & 0.12 & 1.59 & 0.53 \\
\hline Floors & 9 & 3.42 & 6.08 & 1.83 & 1.36 & 0.45 \\
\hline Platforms & 5 & 5.50 & 6.08 & 3.30 & 1.23 & 0.55 \\
\hline Drains & 24 & 5.32 & 7.78 & 2.00 & 1.54 & 0.31 \\
\hline Refrigeration systems & 3 & 1.74 & 2.48 & 0.52 & 1.06 & 0.61 \\
\hline Subtotal & 61 & 4.01 & 7.78 & 0.12 & 1.88 & 0.24 \\
\hline \multicolumn{7}{|l|}{ Products } \\
\hline Bovine carcasses & 134 & 2.24 & 4.73 & -0.05 & 1.13 & 0.10 \\
\hline Swine carcasses & 3 & 3.78 & 3.78 & 3.78 & 0.00 & \\
\hline Ground beef & 12 & 4.30 & 5.78 & 3.00 & 0.95 & 0.28 \\
\hline Comercial cuts & 48 & 2.48 & 4.73 & 0.56 & 1.15 & 0.17 \\
\hline Cooked sausages & 2 & 2.85 & 3.00 & 2.70 & 0.21 & 0.15 \\
\hline Fresh sausages & 10 & 3.69 & 4.78 & 3.00 & 0.50 & 0.16 \\
\hline Subtotal & 209 & 2.51 & 5.78 & -0.05 & 1.22 & 0.08 \\
\hline Total & 407 & 2.97 & 8.95 & -0.48 & 1.43 & 0.07 \\
\hline
\end{tabular}

beef tenderizers) and surfaces, followed by the application of sanitizers. The efficacy of the proposed procedures in reducing microbiological contamination at the identified locations will be the subject of future studies.

\section{Conclusions}

Deficiencies in meat processing during slaughter involving the hygiene of equipment and facilities are magnified when the products reach commercial establishments. The points displaying the highest levels of contamination in the meat retail establishments, in decreasing order, were stainless steel boxes, beef tenderizers, grinders, knives, mixers, sausage stuffers, plastic boxes, floors and drains and, in the slaughterhouse, sausage stuffing equipment, platforms, floors and drains. The most contaminated products were fresh sausages and ground beef, indicating that food safety procedures must be applied to the entire meat production chain from the producer to the consumer. Therefore, it is imperative for quality tools such as good manufacturing and hygiene practices, hazard analysis and critical control points, microbiological risk evaluation, and quality management to be integrated into the meat processing sector.

\section{References}

1. ABNT - ASSOCIAÇÃO BRASILEIRA DE NORMAS TÉCNICAS. Preparo da amostra para exame microbiológico. p. 03, (NBR 10203). Rio de Janeiro: ABNT, 1988

2. BORCH, E.; ARINDER. P. Bacteriological safety issues in beef and ready-to-eat meat products, as well as control measures. Meat Science, Savoy, v. 62, n. 3, p. 381-390, 2002.

3. BRASIL. ANVISA - AGÊNCIA NACIONAL DE VIGILÂNCIA SANITÁRIA. Resolução - RDC n. 12. Aprova o Regulamento Técnico sobre padrões microbiológicos para alimentos. Diário Oficial da União, Brasília, 10 janeiro 2001.

4. DILLON, V. M. Yeasts and moulds associated with meat and meat products. In: DAVIES, A.; BOARD, R. (Eds.) The Microbiology of Meat and Poultry. London: Blackie Academic and Professional, 1998, p. 85-117.

5. EISEL, W. G.; LINTON, R. H.; MURIANA, P. M. A survey of microbial levels for incoming raw beef, environmental sources, and ground beef in a processing plant. Food Microbiology, Illinois, v. 14, n. 3, p. 273-282, 1997.

6. GILL, C. O.; McGINNIS, J. C.; BADONI, M. Use of total or Escherichia coli counts to assess the hygienic characteristics of 
Table 6. Statistical parameters of yeast counts $\left(\log\right.$ CFU. $\mathrm{cm}^{-2}$ or g) in samples of equipment, installations, meat and meat products collected from 10 meat retail establishments and 1 slaughterhouse in Brazil.

\begin{tabular}{|c|c|c|c|c|c|c|}
\hline \multirow[t]{2}{*}{ Samples } & \multicolumn{6}{|c|}{ Yeasts } \\
\hline & $\mathrm{n}$ & Log Mean & Min & Max & Standard deviation & Standard error \\
\hline Beef tenderizer & 7 & 2.53 & -0.48 & 4.08 & 1.53 & 0.58 \\
\hline Plastic boxes & 25 & 3.80 & 0.60 & 6.52 & 1.31 & 0.26 \\
\hline Stainless steel boxes & 10 & 3.75 & 2.18 & 5.18 & 1.13 & 0.36 \\
\hline Sausage stuffers & 3 & 3.45 & -0.48 & 5.66 & 3.41 & 1.97 \\
\hline Knives & 19 & 2.62 & 0.92 & 3.52 & 0.83 & 0.19 \\
\hline Hooks & 10 & 5.91 & 3.65 & 8.00 & 1.28 & 0.40 \\
\hline Tables & 19 & 2.63 & -0.48 & 4.15 & 1.09 & 0.25 \\
\hline Mixers & 4 & 3.46 & 2.18 & 5.42 & 1.41 & 0.71 \\
\hline Grinders & 9 & 3.67 & 2.18 & 6.34 & 1.40 & 0.47 \\
\hline Meat saw & 9 & 2.08 & 0.52 & 3.44 & 0.94 & 0.31 \\
\hline \multicolumn{7}{|l|}{ Installations } \\
\hline Walls & 9 & 3.11 & 0.92 & 5.52 & 1.45 & 0.48 \\
\hline Floors & 9 & 3.37 & 2.34 & 6.30 & 1.27 & 0.42 \\
\hline Platforms & 5 & 6.20 & 5.97 & 6.30 & 0.15 & 0.07 \\
\hline Drains & 24 & 5.26 & 3.08 & 8.00 & 1.36 & 0.28 \\
\hline Refrigeration systems & 3 & 1.64 & 0.52 & 2.22 & 0.97 & 0.56 \\
\hline Subtotal & 61 & 4.10 & -0.48 & 8.00 & 1.82 & 0.23 \\
\hline \multicolumn{7}{|l|}{ Products } \\
\hline Bovine carcasses & 134 & 2.16 & -0.05 & 6.51 & 1.29 & 0.11 \\
\hline Swine carcasses & 3 & 3.78 & 3.78 & 3.78 & 0.00 & \\
\hline Ground beef & 12 & 4.11 & 2.00 & 6.00 & 1.55 & 0.45 \\
\hline Comercial cuts & 48 & 2.07 & -0.05 & 6.94 & 1.63 & 0.23 \\
\hline
\end{tabular}

a beef carcass dressing process. International Journal of Food Microbiology, Copenhagen, v. 31, n. 1-3, p. 181-196, 1996a.

7. GILL, C. O. et al. The hygienic condition of manufacturing beef destined for the manufacture of hamburger patties. Food Microbiology, Illinois, v. 13, n. 5, p. 391-396, 1996b.

8. GILL, C. O. et al. Evaluation of the hygienic performances of the processes for beef carcass dressing at 10 packing plants. Journal of Applied Microbiology, Bedford, v. 84, n. 6, p. 1050-1058, 1998.

9. GILL, C. O. Microbiological contamination of meat during slaughter and butchering of cattle, sheep and pigs. In: DAVIES, A.; BOARD, R. (Eds.) The Microbiology of Meat and Poultry. London: Blackie Academic and Professional, 1998, p. 118-157.

10. GILlesPiE, I.; LitTle, C.; MitChELL, R. Microbiological examination of cold ready-to-eat sliced meats from catering establishments in the United Kingdom. Journal of Applied Microbiology, Bedford, v. 88, n. 3, p. 467-474, 2000.

11. HOOD, S. K.; ZOTTOLA, E. A. Biofilms in food processing. Food Control, Reading, v. 6, n. 1, p. 9-18, 1995.

12. HUDSON, W. R.; MEAD, G. C.; HINTON, M. Assessing abattoir hygiene with a marker organism. Veterinary Records, London, v. 142 , n. 20 , p. 542-547, 1998.
13. JACKSON, T. C.; ACUFF, G. R.; DICKSON, J. S. Meat, Poultry and Seafood. In: DOYLE, M. P.; BEAUCHAT, L. R.; MONTVILLE, L. (Eds.) Food Microbiology. Washington: American Society for Microbiology, 1997, p. 83-99.

14. JAY, J. M. Indicators of Food Microbial Quality and Safety. In: JAY, J. M.; LOESSNER, M. J.; GOLDEN, D. A. (Eds) Modern Food Microbiology. Berkely: Springer, 2005, p. 387-409.

15. PHILLIPS, D.; et al. Microbiological quality of Australian beef. Journal of Food Protection, Des Moines, v. 64, n. 5, p. 692-696, 2001.

16. SUMNER, J. et al. Microbial contamination on beef and sheep carcasses in South Australia. International Journal of Food Microbiology, Copenhagen, v. 81, n. 3, p. 255-260, 2003.

17. USDA - UNITED STATES DEPARTMENT OF AGRICULTURE. Food Safety and Inspection Service. Pathogen Reduction / Hazard Analysis and Critical Control Point (HACCP) Systems / Specific Sample Collection Procedure CRF / Part 304, Rules and Regulations 38931, Washington: USDA, v. 144, n. 61, 1996. 